\title{
Caring for HIV/AIDs orphans in Uganda
}

Published at www.cmaj.ca on Sept. 15

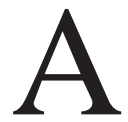
t 680 grams, Ava was the tiniest baby received as of last January by the Bulrushes baby home in Kampala, Uganda.

Abandoned in this bustling city of 1.4 million, she was covered in bugs when she was found a few hours after her birth and taken to a local hospital, where staff called Watoto Child Care Ministries, the church-based organization that runs Bulrushes.

No one was sure the scrawny infant would survive. Only one hospital in Kampala has a ventilator, and most hospital incubators don't work well, says Annie Duguid, team leader for three Watoto baby homes in Uganda. Ava arrived jaundiced and cold, with a body temperature was 34.5 degrees.

"Usually a 1.5-pound baby ends up on oxygen and on a ventilator (in North America)," Duguid says.

Bulrushes has working incubators but no ventilators. They also have a one-nanny-to-four-babies staff ratio and a commitment to provide each of the 2000 children in their care with a family for life.

Watoto Child Care Ministries was established by Canadians Gary and Marilyn Skinner after they arrived in Kampala in 1983 and encountered impoverished grandmothers caring for multiple grandchildren who'd been orphaned at the height of the HIV/AIDS crisis, then-epicentered in Uganda.

"We had the highest infection rate in the world at that time. I just felt so strongly God say: 'Look after my children'," says Gary Skinner.

Within 10 years, the couple had taken on the task of parenting HIV/AIDS-affected children. They now run three villages populated by 260 mothers they have hired to care for up to eight children each, as well as three baby homes (including one in Gulu, in northern Uganda). Each village has schools, a medical clinic and homes, often built by teams of volun-

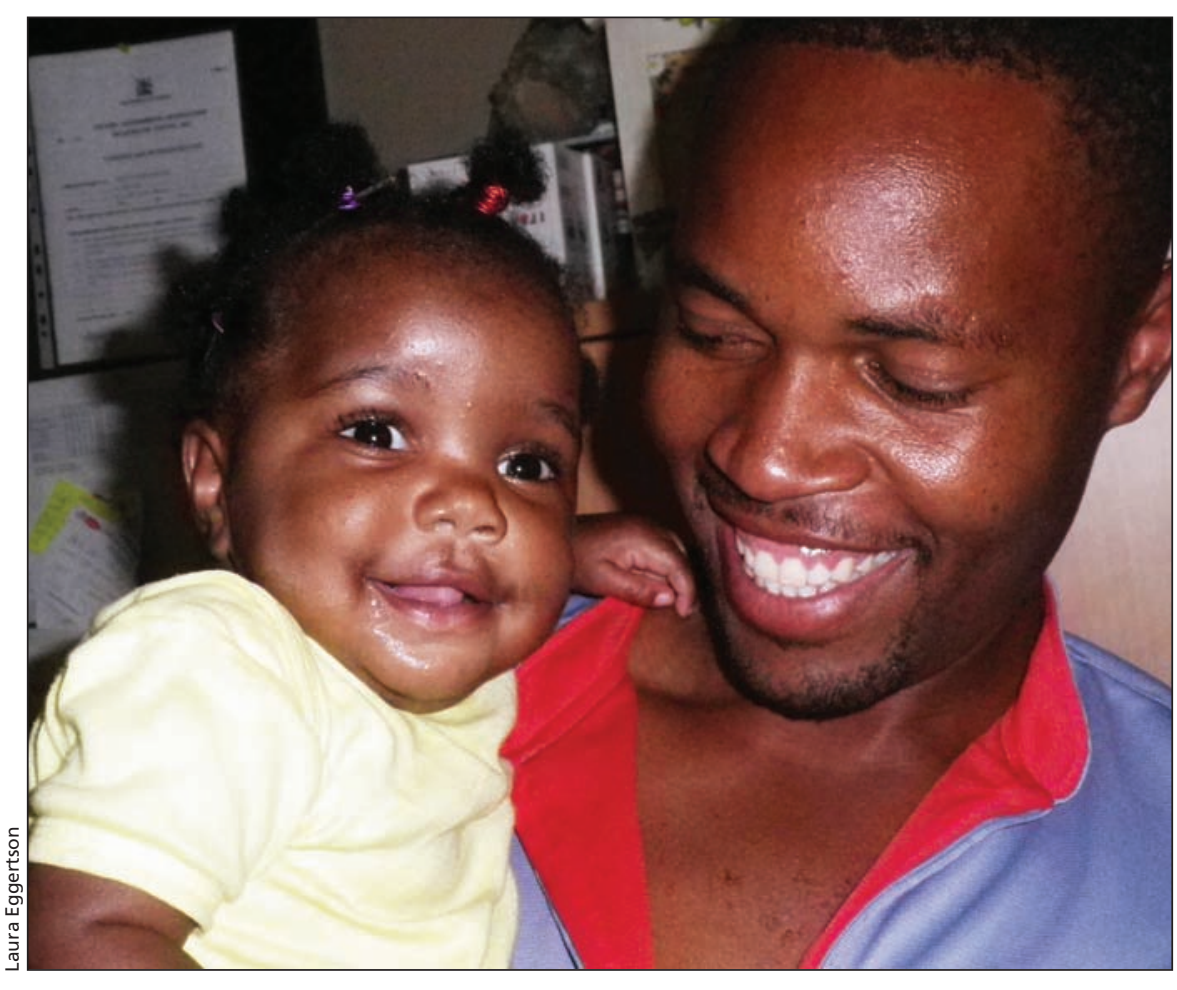

Fred Erisata, one of the first children to have been taken in and raised by the Watoto program, holds one of the latest additions to the Bulrushes baby home.

teers from North America, Hong Kong, and Australia, and equipped with electricity, running water and flush toilets.

Uganda has little in the way of a public safety net, so dozens of churches, charities and nongovernmental organizations run orphanages and baby homes. It's a necessity - there are an estimated two million orphans in the East African country. About 1.2 million of those have lost one or both parents to HIV/AIDS, according to the AIDs Commission of Uganda.

Most baby homes, though, are not equipped to care for extremely premature or sickly babies like Ava, whom Duguid estimates was born at about 28 weeks' gestation. “They're very costly to keep alive, and some will die, and people don't want that on their statistics," she bluntly notes. "We don't really want that on our stats either, but we'd rather try to keep them alive."
Ava received oxygen, intravenous therapy to remind her to breathe, and phototherapy to clear up her jaundice. She is now a chubby, smiling eightmonth-old, close to meeting developmental milestones for her adjusted age.

But regular feeding, oxygen and working incubators don't save all babies. Topping Duguid's wish list is access to pediatricians, neonatologists, ventilators and the respiratory specialists to support them.

Sometimes, the Bulrushes staff can't do anything for babies who won't make it without ventilators, so "we hold them and love them," says Duguid. "If they get to that point, it's pretty much over."

Watoto's baby homes receive an average 15 infants a month who have either been abandoned or had their mothers die in childbirth. Initially, many are HIV-positive but that status often changes once they are given antiretrovirals and their mothers' antibodies 
clear their system. Only $1 \%$ of all the babies in Watoto villages and baby homes are HIV-positive.

Babies graduate to the villages once they are healthy and 15-18 months old. They join toddlers, preteens and teenagers. Under Watoto's holistic model, the children will forever have a family; even after they've completed university (Watoto pays for postsecondary education and supports graduates for a few months after they've finished their education).

"I wouldn't want my children being moved around and I wouldn't want them to grow up feeling that they were foster children," says Skinner. "These kids ... are not a number in a program. They are a name in a family. They never graduate out of the program. That mother is always going to be their mother, and that will always be their home."

In 2009,56 of the first batch of Watoto children completed postsecondary schooling. One of them, 24-year-old Fred Erisata, embraces the Watoto "Rescue, Raise, Rebuild" mandate. The Skinners believe he and all the other rescued children will become Uganda's next leaders.

"I'm no longer a liability to this nation. I'm going to be a productive citizen of Uganda,' says Erisata, who completed law school and plans to run for city council. "I want to influence the politics of this country."

Were it not for the efforts of aid organizations such as Watoto, many Ugandan children would undoubtedly die. Abortion is illegal here. Babies, many of them premature and born to teenagers living on the street, are often left in pit latrines and garbage dumps.

"We know families will usually not have a young girl back with a baby, regardless of whether she was raped," Duguid says. So many girls induce labour and abandon the baby so that they can return to their families.

Because about $13 \%$ of all children in Uganda die before reaching their fifth birthday, it's sometimes hard to foster urgency in hospital staff caring for premature infants, Duguid says. She often visits hospital wards on weekends, afraid that a fragile infant has arrived and will die before social service staff arrive on Monday and call Watoto.

On one such visit, Duguid found Kenneth, an infant who was dying of prematurity in one ward while his mother died of AIDS in another. She propped him up beside his mother so he would someday have one picture of her, at least. Then she took him back to Bulrushes, where they nursed him back to health. - Laura Eggertson, Kampala, Uganda

DOI:10.1503/cmaj.109-3670

Laura Eggertson, a long-time $C M A J$ correspondent, penned this story while in Uganda working as a volunteer for a Watoto Child Ministries building team. 